\title{
EXTRACT OF BARBERRY AS ENTIRELY GREEN CATALYST FOR THE SYNTHESIS OF STRUCTURALLY DIVERSE 3,4,5-SUBSTITUTED FURAN-2(5H)-ONES
}

\author{
Nourallah Hazeri ${ }^{\mathrm{a}^{*}}$, Razieh Doostmohammadia , Belgheis Adrom ${ }^{\mathrm{a}}$, \\ Mojtaba Lashkari ${ }^{\mathrm{b}}$, Malek Taher Maghsoodlou ${ }^{\mathrm{a}}$ \\ ${ }^{a}$ Faculty of Science, University of Sistan and Baluchestan, Zahedan P.O. Box 98135-674, Iran \\ ${ }^{b}$ Faculty of Science, Velayat University, Iranshahr P.O. Box 9911131311, Iran \\ *email:nhazeri@chem.usb.ac.ir;n_hazeri@yahoo.com
}

\begin{abstract}
An eco-friendly and environmentally benign synthesis of 3,4,5-substituted furan-2(5H)-ones employing Iranian seedless barberry, known as Zereshk, (Berberis integerrima "Bidaneh", Berberidaceae) as a biocatalyst, was developed. For the first time, we found that the barberry juice could be effectively used for three-component condensation reaction of aldehydes, amines, and dialkyl acetylenedicarboxylates. The merits of this method include the environmentally friendly reaction conditions, simple operation, broad substrate, satisfying yields, and the generation of less waste rather than the conventional chemical reagents.
\end{abstract}

Keywords: three-component reaction, dialkyl acetylenedicarboxylates, furan-2(5H)-ones, aldehydes, barberry juice.

Received: August 2016/Revised final: October 2016/Accepted: October 2016

\section{Introduction}

In recent years, organic research has been mainly focused on the development of greener and eco-friendlier processes that involve the use of alternative reaction media to replace toxic and expensive catalysts or volatile and hazardous solvents like benzene, toluene and methanol, commonly used in organic synthesis. Nowadays, many organic transformations are carried out in water. Water is a unique solvent because it is readily available, inexpensive, nontoxic, and environmentally benign. The applications of an aqueous extract of different fruit juices have witnessed a rapid development. This growing interest in fruit juice is mainly rooted in its biocatalysts, nonhazardous, environmentally benign character, and cost effectiveness [1-3].

In recent years, chemical reactions using plant cell cultures and part of plants as biocatalysts received great attention [4-6]. This crescent interest is due to the wide biotechnological potential of the enzymatic reactions. The biocatalytical alteration using edible plants [7], plant root [8], plant tubers [9], edible plants [10] and plant leaves [11] extract can be applied in many organic reactions. Fruit juice is also a natural product that is used as biocatalysts in organic synthesis. Fruit juice is now being routinely used in organic synthesis as homogeneous catalysts for various selective transformations of simple and complex molecules [12].

Furanones are the five-membered heterocyclic compounds possessing lactone ring in their structures. These heterocycles are the core structures of many bioactive natural products, as well as synthetic drugs, such as rubrolide, sarcophine, benfurodil hemisuccinate, etc. The $5 H$-Furan-2-one derivatives exhibit many pharmacological and biological activities including antifungal, antibacterial, anti-oxidants, anti-inflammatory, anti-microbial and anti cancer agents [13-17].

As a part of our efforts to develop new synthetic methods in heterocyclic chemistry [18-20], herein we report, for the first time, a three-component reaction of aldehydes, amines and dialkyl acetylenedicarboxylates for the synthesis of 3,4,5-substituted furan-2(5H)-one derivatives in barberry juice as an eco-friendly catalyst (Scheme 1). This approach offers an alternative method of construction of furanone architectures with potential biological activities based on a concise, rapid, and environmentally friendly vision.

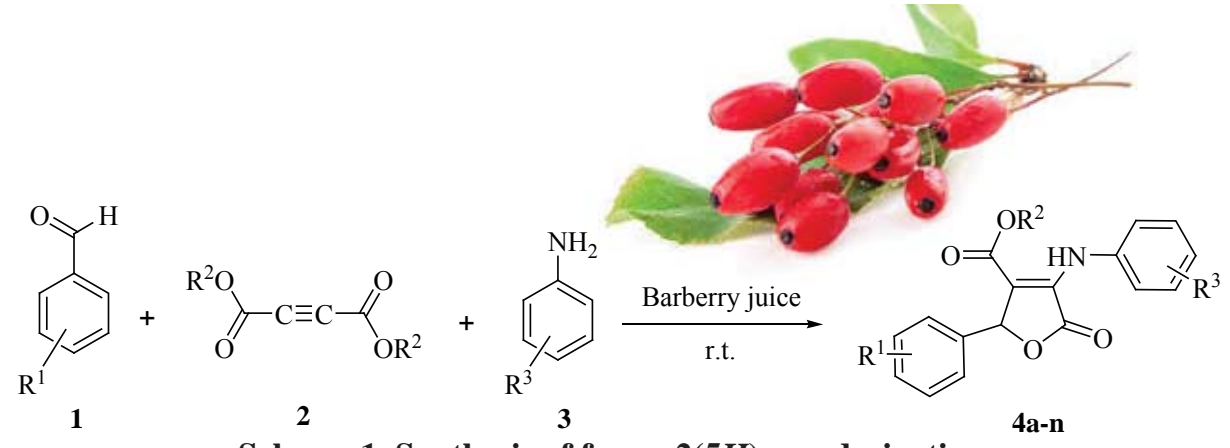

Scheme 1 . Synthesis of furan-2(5H)-one derivatives. 


\section{Results and discussion}

In continuation of our work following the principles of green chemistry [17-20], we have developed a simple, efficient, and green protocol for the preparation of 3,4,5-substituted furan-2(5H)-one, using an extract of barberry as a green and inexpensive catalyst and solvent. Our approach reduces the use of hazardous organic solvents and uses simple and mild conditions with inherently lower costs.

Different types of barberry are well known around the world for several benefits, such as medical, ornamental and food uses. Iranian seedless barberry (Berberis integerrima "Bidaneh") is commercially cultivated for its fruit in Iran, especially in South Khorasan province. Currently, there are over 11,000 ha of cultivated seedless barberry, annually producing more than 9200 tonnes of dried fruit [21]. Some studies have found that barberry has some important bioactive components in roots and/or fruits, such as calcium, sodium, sulphur, iron, zinc, vitamin C, carbohydrates, organic acids and alkaloids, e.g. berberine and palmatine $[22,23]$.<smiles></smiles>

(a)<smiles>COc1cc2c(cc1OC)-c1cc3ccc(OC)c(OC)c3[n+](c1)CC2</smiles>

(b)

Figure 1. Chemical structures of berberine (a) and palmatine (b).

Among active components of barberry, the alkaloid berberine (Figure 1) occurring in bark of root, stem and unripe fruit, is considered the most important active constituent of the plant. Berberine, a yellow colour bitter substance [24], belongs to a large and diverse group of alkaloids called benzylisoquinolines [25]. Soluble sugars and berberine content of the barberry are one of its most important properties, since the value of the barberry is dependent on this content. The sugars were applied as an efficient and homogenous catalyst for multicomponent reaction in excellent yields $[26,27]$.

Our further experiments have been designed to check the activities of some components of barberry juice on the synthesis of 3,4,5-substituted furan-2(5H)-one. For this purpose in separate experiments, components of barberry juice with the highest percentage, such as glucose, fructose, and vitamin $\mathrm{C}$ were selected. Investigations showed that the reaction occurred in the presence of all above components in good yield. Since the juice contains so many vitamins, ions and reducing sugars with different ratio and varieties, regarding to the mentioned experiment, it seems that a set of above agents are effective in occurring of this three component reaction.

At the beginning, a test reaction was performed using benzaldehyde $\mathbf{1}(1.0 \mathrm{mmol})$, aniline 3 (1.0 mmol) and dimethyl acetylenedicarboxylate $2(1.0 \mathrm{mmol})$ in $5 \mathrm{~mL}$ juice of barberry at room temperature, in order to establish the real effectiveness of the catalyst/solvent, and the product was obtained in good yields.

In order to compare the strength of the juice of barberry and a catalyst with juice of various summer fruits, a model reaction was carried out between benzaldehyde $\mathbf{1}(1.0 \mathrm{mmol})$, aniline $\mathbf{3}(1.0 \mathrm{mmol})$ and dimethyl acetylenedicarboxylate 2 $(1.0 \mathrm{mmol})$, using various fruit juices as catalysts at room temperature, and the results were summarized in Table 1 .

Table 1

Optimization of catalyst for the synthesis of furan-2(5H)-ones.

\begin{tabular}{lcccc}
\hline Entry & Solvent & $p H$ & Time $(h)$ & Isolated yield $(\%)$ \\
\hline 1 & $\mathrm{H}_{2} \mathrm{O}$ & 6.8 & 24 & - \\
2 & melon juice & 5.8 & 6 & 50 \\
3 & blackberry juice & 3.9 & 15 & 25 \\
4 & grapes juice & 2.9 & 12 & 40 \\
5 & pomegranate juice & 3.0 & 15 & 25 \\
6 & strawberries juice & 3.2 & 24 & - \\
7 & peach juice & 3.3 & 10 & 42 \\
8 & verjuice juice & 3.5 & 16 & 38 \\
9 & barberry juice & $\mathbf{5 . 6}$ & $\mathbf{3}$ & $\mathbf{9 2}$ \\
\hline
\end{tabular}

Reaction conditions: benzaldehyde $(1.0 \mathrm{mmol})$, aniline $(1.0 \mathrm{mmol})$, dimethyl acetylenedicarboxylate $(1.0 \mathrm{mmol})$ in various media at room temperature. 
To explore the scope and generality of the presented multicomponent reaction protocol for the synthesis of 3,4,5-substituted furan-2(5H)-one under the optimized conditions, a variety of aromatic aldehydes containing electron donating or electron withdrawing substituents in the aromatic ring, such as $-\mathrm{Me},-\mathrm{Cl},-\mathrm{OMe}$ and $-\mathrm{NO}_{2}$ were reacted with dialkyl acetylenedicarboxylate and various anilines to furnish diverse furan-2(5H)-one. The results were summarized in Table 3. In all cases, aromatic aldehydes with substituents carrying either electron-donating or electron-withdrawing groups reacted successfully and gave the products in high yields. It was found that aromatic aldehydes with electronwithdrawing groups reacted faster than those with electron-donating groups, as would be expected. The results were shown in Table 2.

Table 2

Synthesis of furan-2(5H)-one derivatives.

\begin{tabular}{|c|c|c|c|c|c|c|c|c|}
\hline \multirow[t]{2}{*}{ Entry } & \multirow[t]{2}{*}{$R^{1}$} & \multirow[t]{2}{*}{$R^{2}$} & \multirow[t]{2}{*}{$R^{3}$} & \multirow{2}{*}{$\begin{array}{c}\text { Time } \\
\text { (h) }\end{array}$} & \multirow{2}{*}{$\begin{array}{l}\text { Isolated } \\
\text { yield }(\%)\end{array}$} & \multirow[t]{2}{*}{ Product } & \multicolumn{2}{|c|}{ M.p. $\left({ }^{\circ} \mathrm{C}\right)$} \\
\hline & & & & & & & This work & Lit. [Ref]] \\
\hline 1 & $\mathrm{Ph}$ & $\mathrm{CH}_{3}$ & $4-\mathrm{F}-\mathrm{C}_{6} \mathrm{H}_{4}$ & 2.5 & 70 & $4 a$ & $293-295$ & $293-295$ [13] \\
\hline 2 & $\mathrm{Ph}$ & $\mathrm{CH}_{3}$ & $4-\mathrm{Cl}-\mathrm{C}_{6} \mathrm{H}_{4}$ & 1.5 & 75 & $4 b$ & $150-152$ & $149-152[17]$ \\
\hline 3 & $\mathrm{Ph}$ & $\mathrm{CH}_{3}$ & $3-\mathrm{NO}_{2}-\mathrm{C}_{6} \mathrm{H}_{4}$ & 2.5 & 85 & $4 c$ & $178-181$ & $179-182[17]$ \\
\hline 4 & $4-\mathrm{NO}_{2}-\mathrm{C}_{6} \mathrm{H}_{4}$ & $\mathrm{CH}_{3}$ & $\mathrm{Ph}$ & 0.5 & 94 & $4 d$ & $128-130$ & $130-131$ [17] \\
\hline 5 & $\mathrm{Ph}$ & $\mathrm{CH}_{3} \mathrm{CH}_{2}$ & $\mathrm{Ph}$ & 0.5 & 90 & $4 \mathrm{e}$ & $163-165$ & $164-166[12]$ \\
\hline 6 & $4-\mathrm{Me}-\mathrm{C}_{6} \mathrm{H}_{4}$ & $\mathrm{CH}_{3} \mathrm{CH}_{2}$ & $\mathrm{Ph}$ & 1 & 90 & $4 f$ & $119-121$ & $120-121[12]$ \\
\hline 7 & $4-\mathrm{OMe}-\mathrm{C}_{6} \mathrm{H}_{4}$ & $\mathrm{CH}_{3}$ & $\mathrm{Ph}$ & 1.5 & 67 & $4 \mathrm{~g}$ & $239-242$ & $239-242[17]$ \\
\hline 8 & $4-\mathrm{Me}-\mathrm{C}_{6} \mathrm{H}_{4}$ & $\mathrm{CH}_{3}$ & $\mathrm{Ph}$ & 2 & 85 & $4 \mathrm{~h}$ & $181-183$ & $181-183$ [13] \\
\hline 9 & $4-\mathrm{Cl}-\mathrm{C}_{6} \mathrm{H}_{4}$ & $\mathrm{CH}_{3}$ & $\mathrm{Ph}$ & 2 & 75 & $4 \mathrm{i}$ & $149-152$ & $149-152[12]$ \\
\hline 10 & $\mathrm{Ph}$ & $\mathrm{CH}_{3}$ & $4-\mathrm{Me}-\mathrm{C}_{6} \mathrm{H}_{4}$ & 1 & 90 & $4 j$ & $284-287$ & $284-287$ [12] \\
\hline 11 & $\mathrm{Ph}$ & $\mathrm{CH}_{3} \mathrm{CH}_{2}$ & $4-\mathrm{Me}-\mathrm{C}_{6} \mathrm{H}_{4}$ & 1 & 80 & $4 \mathrm{k}$ & $185-186$ & $188-191[12]$ \\
\hline 12 & $\mathrm{Ph}$ & $\mathrm{CH}_{3} \mathrm{CH}_{2}$ & $3-\mathrm{NO}_{2}-\mathrm{C}_{6} \mathrm{H}_{4}$ & 3 & 84 & 41 & $208-210$ & 208 [28] \\
\hline 13 & $4-\mathrm{Me}-\mathrm{C}_{6} \mathrm{H}_{4}$ & tert-buthyl & $\mathrm{Ph}$ & 2 & 90 & $4 \mathrm{~m}$ & $176-178$ & $175-178$ [28] \\
\hline 14 & $\mathrm{Ph}$ & $\mathrm{CH}_{3}$ & $\mathrm{Ph}$ & 0.5 & 96 & $4 n$ & $158-160$ & $159-162[13]$ \\
\hline 15 & $3-\mathrm{NO}_{2}-\mathrm{C}_{6} \mathrm{H}_{4}$ & $\mathrm{CH}_{3}$ & $\mathrm{Ph}$ & 1 & 95 & 40 & $200-202$ & $203-205$ [13] \\
\hline 16 & $\mathrm{Ph}$ & tert-buthyl & $4-\mathrm{Me}-\mathrm{C}_{6} \mathrm{H}_{4}$ & 6 & 85 & $4 p$ & $185-187$ & - \\
\hline 17 & $\mathrm{Ph}$ & tert-buthyl & $4-\mathrm{Cl}-\mathrm{C}_{6} \mathrm{H}_{4}$ & 10 & 84 & $4 q$ & $169-171$ & - \\
\hline 18 & $\mathrm{Ph}$ & tert-buthyl & $4-\mathrm{F}-\mathrm{C}_{6} \mathrm{H}_{4}$ & 10 & 83 & $4 \mathrm{r}$ & $170-173$ & - \\
\hline
\end{tabular}

A proposed mechanism for the discussed transformation can be combined with the nucleophilic Michael addition, iminium-enamine tautomerization and $\gamma$-lactonization [16-20] (Scheme 2).

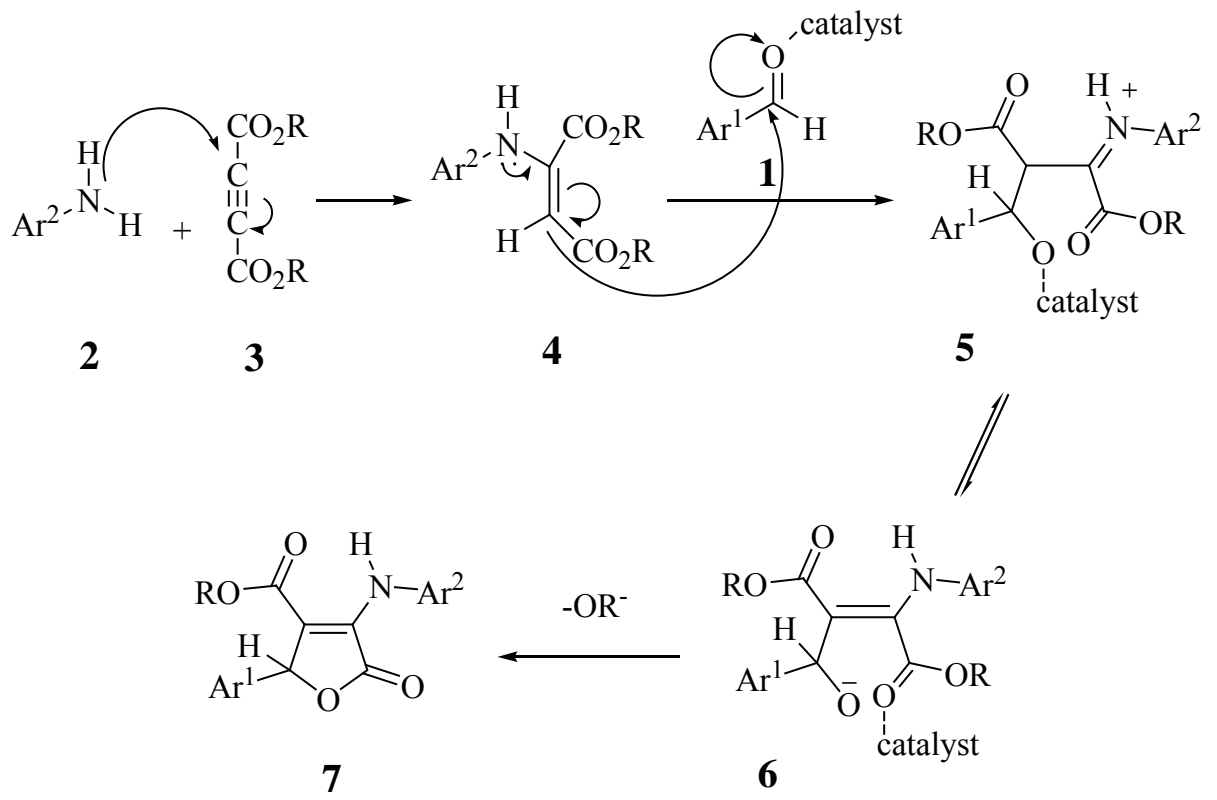

Scheme 2. Suggested mechanism for synthesis of furan-2(5H)-ones. 
The structures of new compounds presented in Table 3 were deduced on the basis of IR, ${ }^{1} \mathrm{H}$ and ${ }^{13} \mathrm{C}$ NMR spectroscopy, mass spectrometry, and elemental analysis. The mass spectrum of compound tert-butyl 4-( $p$-tolylamino)2,5-dihydro-5-oxo-2-phenylfuran-3-carboxylate 4p, displayed the molecular ion peak at $\mathrm{m} / \mathrm{z}=365$ that is consistent with the proposed structure. The ${ }^{1} \mathrm{H}$ NMR spectrum of this product exhibited a singlet at $\delta=1.35$ ppm and singlet at $\delta=2.25 \mathrm{ppm}$ for tert-butyl protons of the carboxylate group and one sharp singlet arising from benzylic proton at $\delta=5.63 \mathrm{ppm}$. The aromatic protons of product were observed at $\delta=7.06-7.35 \mathrm{ppm}$. A broad singlet for the NH group at $\delta=9.09$ ppm indicated intra-molecular hydrogen bond formation with the vicinal carbonyl group. The ${ }^{13} \mathrm{C}$ NMR spectrum of this product showed 16 distinct resonances consistent with the proposed structure. The IR spectrum indicated one sharp peak at $3305 \mathrm{~cm}^{-1}$ for NH within the product. To compare the applicability and efficiency of barberry juice with the reported catalysts in the literature for the synthesis of 3,4,5-substituted furan-2(5H)-ones, we have tabulated the results of these catalysts in Table 3. As shown in Table 4, barberry juice can act as an efficient catalyst in terms of reaction time and yield of products.

Comparison of using barberry juice and the reported catalysts for the synthesis of

Table 3 3,4,5-substituted furan-2(5H)-ones $4 \mathrm{n}$.

\begin{tabular}{|c|c|c|c|c|c|}
\hline Entry & Product & Catalyst & Time (h) & Yield (\%) & Reference \\
\hline 1 & $4 n$ & nano-ZnO & 2.5 & 94 & {$[16]$} \\
\hline 2 & & $\mathrm{Al}\left(\mathrm{HSO}_{4}\right)_{3}$ & 8 & 84 & {$[15]$} \\
\hline 3 & & $\mathrm{SnCl}_{2} \cdot 2 \mathrm{H}_{2} \mathrm{O}$ & 6.5 & 90 & [14] \\
\hline 4 & & {$\left[\mathrm{Bu}_{4} \mathrm{~N}\right]\left[\mathrm{HSO}_{4}\right]$} & 5 & 92 & [19] \\
\hline 5 & & $\mathrm{PPA} / \mathrm{SiO}_{2}$ & 1 & 90 & [18] \\
\hline 6 & & sucrose & 9 & 97 & {$[27]$} \\
\hline 7 & & barberry juice & 0.5 & 96 & This work \\
\hline
\end{tabular}

\section{Conclusions}

In conclusion, we have found that the aqueous extract of barberry is as an efficient, economical, and environmentally-friendly catalyst for the synthesis of 3,4,5-substituted furan-2(5H)-ones. The high yield of products in a short reaction time with high purity, mild reaction conditions, and a simple workup procedure make this procedure attractive. The use of barberry juice both as a solvent and biodegradable catalyst is the attractive feature of this protocol. Furnishing pure products by simple filtration makes an aqueous approach possible for large scale preparation of furan-2(5H)-ones.

\section{Experimental}

Melting points and IR spectra of all compounds were measured on an Electrothermal 9100 apparatus and a JASCO FTIR 460 Plus spectrometer respectively. The ${ }^{1} \mathrm{H}$ and ${ }^{13} \mathrm{C}$ NMR spectra were obtained on Bruker DRX-400 Avance instruments with $\mathrm{CDCl}_{3}$ as a solvent. Mass spectra were recorded on an Agilent Technology (HP) spectrometer operating at an ionization potential of $70 \mathrm{eV}$. Samples of fruits were blended using a laboratory electrical blender (Model 32BL79, Waring, USA). All reagents and solvents obtained from Fluka and Merck were used without further purification.

\section{Plant material}

Eight samples of fruits were purchased from the local commercial market, collected in the period between July and August (2013) in the region of the South of Sistan and Baluchestan and South Khorasan, Iran. The purchased samples were washed and drained. The skins of them except blackberry and barberry were peeled and the rest of the fruit was cut into $3 \mathrm{~cm}$ cubes. The seeds were then removed and all flesh parts were blended using a laboratory electrical blender (Model 32BL79, Waring, USA). The obtained juice was vacuum- filtered and then transferred into a beaker.

\section{General procedure for the synthesis of furan-2(5H)-one derivatives}

The mixture of aldehyde $(1.0 \mathrm{mmol})$, amine $(1.0 \mathrm{mmol})$, dialkyl acetylenedicarboxylate $(1.0 \mathrm{mmol})$ and $5 \mathrm{~mL}$ juice of barberry were stirred at room temperature. After completion of the reaction (monitored by thin-layer chromatography, TLC), the reaction products were collected by filtration. The products were washed with water/ethanol $(1: 1,3 \times 2 \mathrm{~mL})$ to give the corresponding pure compounds. The catalyst remained in the water/ethanol filtrate.

Methyl 2,5-dihydro-5-oxo-2-phenyl-4-(phenylamino)furan-3-carboxylate (4n). White solid: 0.296 g (96 \%); m.p. $158-160{ }^{\circ} \mathrm{C}$; IR (KBr): 3260, 3208, 1702, $1661 \mathrm{~cm}^{-1}$; ${ }^{1} \mathrm{H}$ NMR $\left(400 \mathrm{MHz}, \mathrm{CDCl}_{3}\right) \delta$, ppm: 3.77 (s, 3H, OCH $)$, $5.76\left(\mathrm{~s}, 1 \mathrm{H}, \mathrm{H}_{\text {benzylic }}\right), 7.13\left(\mathrm{t}, J=7.3 \mathrm{~Hz}, 1 \mathrm{H}_{\text {aromatic }}\right), 7.24-7.31(\mathrm{~m}, 6 \mathrm{H}), 7.52\left(\mathrm{~d}, J=8 \mathrm{~Hz}, 2 \mathrm{H}, \mathrm{H}_{\text {aromatic }}\right), 8.90(\mathrm{br}, 1 \mathrm{H}, \mathrm{NH})$. 
Tert-butyl 4-(p-tolylamino)-2,5-dihydro-5-oxo-2-phenylfuran-3-carboxylate (4p). Colorless solid; $0.287 \mathrm{~g}$ (85 \%); m.p. $185-187^{\circ} \mathrm{C}$; IR (KBr): 3305, 3030, 1690, $1666 \mathrm{~cm}^{-1} ;{ }^{1} \mathrm{H}$ NMR $\left(400 \mathrm{MHz}, \mathrm{CDCl}_{3}\right) \delta$, ppm: $1.35\left(\mathrm{~s}, 9 \mathrm{H}, \mathrm{CH}_{3}\right), 2.25$ $\left(\mathrm{s}, 3 \mathrm{H}, \mathrm{CH}_{3}\right), 5.63\left(\mathrm{~s}, 1 \mathrm{H}, \mathrm{H}_{\text {benzylic }}\right), 7.06-7.35\left(\mathrm{~m}, 9 \mathrm{H}, \mathrm{H}_{\text {aromatic }}\right), 9.09$ (br, $\left.1 \mathrm{H}, \mathrm{NH}\right) ;{ }^{13} \mathrm{C} \mathrm{NMR}\left(100 \mathrm{MHz} \mathrm{CDCl}_{3}\right) \delta, \mathrm{ppm}$ 165.1 and 162.9 (CO of ester), 157.0, 135.6, 135.4, 133.7, 129.5, 128.4, 128.5, 127.6, 122.5, $114.3\left(10 \mathrm{C}_{\text {aromatic }}\right), 83.2$ (C-O), $61.8\left(\mathrm{C}_{\text {benzylic }}\right), 27.9\left(3 \mathrm{CH}_{3}\right), 20.9\left(\mathrm{CH}_{3}\right) ; \mathrm{MS} \mathrm{m} / \mathrm{z}(\%): 57$ (42), 77 (25), 102 (39), 130 (100), 158 (42), 175 (24), 263 (29), 291 (39), 309 (52), $365\left(\mathrm{M}^{+}, 28\right)$.

Tert-butyl 4-(4-chlorophenylamino)-2,5-dihydro-5-oxo-2-phenylfuran-3-carboxylate (4q). Colourless solid; 0.268 g (84 \%); m.p. $169-171{ }^{\circ} \mathrm{C}$; IR (KBr): 3315, 3095, 2975, 1690, $1655 \mathrm{~cm}^{-1}$; ${ }^{1} \mathrm{H}$ NMR (400 $\left.\mathrm{MHz} \mathrm{CDCl}_{3}\right) \delta, \mathrm{ppm}$ $1.36\left(\mathrm{~s}, 9 \mathrm{H}, \mathrm{CH}_{3}\right), 5.64\left(\mathrm{~s}, 1 \mathrm{H}, \mathrm{H}_{\text {benzylic }}\right), 7.18-7-47\left(\mathrm{~m}, 9 \mathrm{H}, \mathrm{H}_{\text {aromatic }}\right), 9.36(\mathrm{br}, 1 \mathrm{H}, \mathrm{NH}) ;{ }^{13} \mathrm{C} \mathrm{NMR}\left(100 \mathrm{MHz} \mathrm{CDCl}_{3}\right)$ $\delta$, ppm: 165.0, $162.9\left(\mathrm{C}_{\text {ester }}\right), 156.6,134.96,134.95,131.0,129.0,128.68,128.60,127.5,123.3,114.6\left(10 \mathrm{C}_{\text {aromatic }}\right.$ and $\left.\mathrm{C}_{\text {vinyl }}\right), 83.5(\mathrm{C}-\mathrm{O}), 61.6\left(\mathrm{C}_{\text {benzylic }}\right), 27.9\left(\mathrm{CH}_{3}\right) ; \mathrm{MS} \mathrm{m} / \mathrm{z}(\%): 57$ (48), 77 (34), 102 (46), $130(100), 158(32), 175$ (76), 284 (36), 329 (92), $311(45), 385\left(\mathrm{M}^{+}, 33\right), 387\left(\mathrm{M}^{+}+2,12\right), 389\left(\mathrm{M}^{+}+4,0.5\right)$.

Tert-butyl 4-(4-fluorophenylamino)-2,5-dihydro-5-oxo-2-phenylfuran-3-carboxylate (4r). Colourless solid; 0.232 g (83 \%); m.p. 170-173 ${ }^{\circ} \mathrm{C}$; IR (KBr): 3260, 3145, 2970, 1689, $1650 \mathrm{~cm}^{-1} ;{ }^{1} \mathrm{H}$ NMR (400 MHz, $\left.\mathrm{CDCl}_{3}\right) \delta, \mathrm{ppm}$ $1.35\left(\mathrm{~s}, 9 \mathrm{H}, \mathrm{CH}_{3}\right), 5.61\left(\mathrm{~s}, 1 \mathrm{H}, \mathrm{H}_{\text {benzylic }}\right), 6.94-7.43\left(\mathrm{~m}, 9 \mathrm{H}, \mathrm{H}_{\text {aromatic }}\right) 9.37$ (br, $\left.1 \mathrm{H}, \mathrm{NH}\right) ;{ }^{3} \mathrm{C} \mathrm{NMR}\left(100 \mathrm{MHz} \mathrm{CDCl}_{3}\right)$ $\delta$, ppm: 165.1, $162.9\left(\mathrm{CO}_{\text {ester }}\right), 160.2\left(\mathrm{~d}, J_{\mathrm{CF}}=245.9 \mathrm{~Hz}\right), 156.8,135.0,132.3\left(\mathrm{~d}, J_{\mathrm{CF}}=3.0 \mathrm{~Hz}\right), 128.6,128.5,127.6,124.4$ $\left(\mathrm{d}, J_{\mathrm{CF}}=8.4 \mathrm{~Hz}\right), 115.8\left(\mathrm{~d}, J_{\mathrm{CF}}=22.6 \mathrm{~Hz}\right), 114.5\left(10 \mathrm{C}_{\text {aromatic }}\right.$ and $\left.\mathrm{C}_{\text {vinyl }}\right), 83.3(\mathrm{C}-\mathrm{O}), 62.0\left(\mathrm{C}_{\text {benzylic }}\right), 27.9\left(\mathrm{CH}_{3}\right) ; \mathrm{MS} \mathrm{m} / \mathrm{z}(\%)$ : 57 (76), 77 (30), 102 (43), 130 (100), 158 (41), 175 (76), 268 (42), 295 (29), 313 (88), 361 (51), 369 (M+ , 29).

\section{Supplementary information}

Supplementary data are available free of charge at http://cjm.asm.md as PDF file.

\section{Acknowledgments}

Baluchestan

We gratefully acknowledge the financial support from the Research Council of the University of Sistan and

\section{References}

1. van der Plas, H.C.; Tramper, J.; Linko, P. Eds. Biocatalysts in Organic Syntheses. $1^{\text {st }}$ Edition. Elsevier: Amsterdam, $1985,25 \mathrm{p}$.

2. Baldassare, F.; Bertoni, G.; Chiappe, C.; Marioni, F. Preparative synthesis of chiral alcohols by enantioselective reduction with daucus carota root as biocatalyst. Journal of Molecular Catalysis B: Enzymatic, 2000, 11, pp. 55-58.

3. Koeller, K.M.; Wong, C.H. Enzymes for chemical synthesis. Nature, 2001, 409(6817), pp. 232-240.

4. Giri, A.; Dhinga, V.; Giri, C.C.; Singh, A.; Ward, O.P.; Narasu, M.L. Biotransformations using plant cells, organ cultures and enzyme systems: current trends and future prospects. Biotechnology Advances, 2001, 19(3), pp. 175-199.

5. Villa, R.; Molinari, F.; Levati, M.; Aragozzini, F. Stereoselective reduction of ketones by plant cell cultures. Biotechnology Letters, 1998, 20(12), pp. 1105-1108.

6. Bruni, R.; Fantin, G.; Medici, A.; Pedrini, P.; Sacchetti, G. Plants in organic synthesis: an alternative to baker's yeast. Tetrahedron Letters, 2002, 43(18), pp. 3377-3379.

7. Comasseto, J.V.; Omori, A.T.; Porto, A.L. M.; Andrade, L.H. Preparation of chiral organochalcogeno- $\alpha-$ methylbenzyl alcohols via biocatalysis. The role of Daucus carota root. Tetrahedron Letters, 2004, 45(3), pp. 473-476.

8. Yadav, J.S.; Reddy, T.; Nanda, S.; Rao, A.B. Stereoselective synthesis of $(R)-(-)$-denopamine, $(R)-(-)$-tembamide and $(R)-(-)$-aegeline via asymmetric reduction of azidoketones by Daucus carota in aqueous medium. Tetrahedron: Asymmetry, 2002, 12(24), pp. 3381-3385.

9. Mironowicz, A. Biotransformations of racemic acetates by potato and topinambur tubers. Phytochemistry, 1998, 47(8), pp. 1531-1534.

10. Andrade, L.H.; Utsunomiya, S.; Omori, A.T.; Porto, A.L.M.; Comasseto, J.V. Edible catalysts for clean chemical reactions: Bioreduction of aromatic ketones and biooxidation of secondary alcohols using plants. Journal of Molecular Catalysis B: Enzymatic, 2006, 38(2), pp. 84-90.

11. Silver, G.M.; Fall, R. Enzymatic synthesis of isoprene from dimethylallyl diphosphate in aspen leaf extracts. Plant Physiology, 1991, 97(4), pp. 1588-1591.

12. Pore, S.; Rashimkar, G.; Mote, K.; Salunkhe, R. Aqueous extract of the pericarp of Sapindus trifoliatus fruits: Anovel 'green' catalyst for the aldimine synthesis. Chemistry \& Biodiversity, 2010, 7, pp. 1796-1800.

13. Narayana Murthy, S.; Madhav, B.; Vijay Kumar, A.; Rama Rao, K.; Nageswar, Y.V.D. Facile and efficient synthesis of 3,4,5-substituted furan-2(5H)-ones by using $\beta$-cyclodextrin as reusable catalyst. Tetrahedron, 2009, 65(27), pp. 5251-5256.

14. Nagarapu, L.; Kumar, U.N.; Upendra, P.; Bantu, R. Simple, Convenient method for the synthesis of substituted furan-2(5H)-one derivatives using tin(ii) chloride. Synthetic Communications, 2012, 42(14), pp. 2139-2148. 
15. Mohammad Shafiee, M.R.; Mansoor, S.S.; Ghashang, M.; Fazlinia, A. Preparation of 3,4,5-substituted furan2(5H)-ones using aluminum hydrogen sulfate as an efficient catalyst. Comptes Rendus Chimie, 2014, 17(2), pp. 131-134.

16. Tekale, S.U.; Kauthale, S.S.; Pagore, V.P.; Jadhav, V.B.; Pawar, R.P. ZnO nanoparticle-catalyzed efficient one-pot three-component synthesis of 3,4,5-trisubstituted furan-2(5H)-ones. Journal of the Iranian Chemical Society, 2013, 10(6), pp. 1271-1277.

17. Ramesh, S.; Nagarajan, R. Efficient one-pot multicomponent synthesis of (carbazolylamino)furan-2(5H)-one and carbazolyltetrahydropyrimidine derivatives. Synthesis, 2011, 20, pp. 3307-3317.

18. Doostmohammadi, R.; Hazeri, N. Application of silica gel-supported polyphosphoric acid ( $\left.\mathrm{PPA} / \mathrm{SiO}_{2}\right)$ as a reusable solid acid catalyst for one-pot multi-component synthesis of 3,4,5-substituted furan-2(5H)-ones. Letters in Organic Chemistry, 2013, 10(3), pp. 199-203.

19. Doostmohammadi, R.; Maghsoodlou, M.T.; Hazeri, N.; Habibi-Khorassani, S.M. An efficient one-pot multicomponent synthesis of 3,4,5-substituted furan-2(5H)-ones catalyzed by tetra- $n$-butylammonium bisulfate. Chinese Chemical Letters, 2013, 24(10), pp. 901-903.

20. Adrom, B.; Hazeri, N.; Maghsoodlou, M.T.; Mollamohammadi, M. Ecofriendly and efficient multicomponent method for preparation of 1-amidoalkyl-2-naphthols using maltose under solvent-free conditions. Research on Chemical Intermediates, 2015, 41(7), pp. 4741-4747.

21. Rezaei, M.; Ebadi, A.; Reim, S.; Reza, F.; Balandary, A.; Farrokhi, N.; Hanke, M.V. Molecular analysis of Iranian seedless barberries via SSR. Scientia Horticulturae, 2011, 129(4), pp. 702-709.

22. Gundogdu, M. Determination of antioxidant capacities and biochemical compounds of Berberis vulgaris L. fruits. Advances in Environmental Biology, 2013, 7(2), pp. 344-348.

23. Pozniakovski1̌, V.M.; Golub, O.V.; Popova, D.G.; Kovalevskaia, I.N. The use of barberry berries in human nutrition. Voprosy pitaniia, 2003, 72(4), pp. 46-49 (in Russian).

24. Arayne, S.M.; Sultana, N.; Bahadur, S.S.; Pak. J. The berberis story: Berberis vulgaris in therapeutics. Pakistan Journal of Pharmaceutical Sciences, 2007, 20(1), pp. 83-92.

25. Kutchan, T.M. Alkaloid biosynthesis-the basis for metabolic engineering of medicinal plants. The Plant Cell, 1995, 7(7), pp. 1059-1070.

26. Mousavi, M.R.; Hazeri, N.; Maghsoodlou, M.T.; Salahi, S.; Habibi-Khorassani, S.M. Entirely green protocol for the synthesis of $\beta$-aminoketones using saccharose as a homogenous catalyst. Chinese Chemical Letters, 2013, 24(5), pp. 411-414.

27. Hazeri, N.; Maghsoodlou, M.T.; Mahmoudabadi, N.; Doostmohammadi, R.; Salahi, S. Sucrose as an environmental and economical catalyst for the synthesis of 2(5H) furanone. Current Organocatalysis, 2014, 1(1), pp. 45-60.

28. Adrom, B.; Maghsoodlou, M.T.; Lashkari, M.; Hazeri, N.; Doostmohammadi, R. Efficient one-pot three-component synthesis of 3,4,5-substituted furan-2(5H)-ones catalyzed watermelon juice. Synthesis and Reactivity in Inorganic, Metal-Organic, and Nano-Metal Chemistry, 2016, 46(3), pp. 423-427. 